The $6^{\text {th }}$ Conf. of SSFOP “Sustainable Development of Ornamental, Medicinal and Aromatic

Plants Scope”, Cairo, Egypt, 1/3/2020

Scientific J. Flowers \& Ornamental Plants

www.ssfop.com/journal

ISSN: 2356-7864

doi: 10.21608/sjfop.2020.91392

\title{
EFFECT OF NIGHT BREAK DURATION AND PACLOBUTRAZOL ON GROWTH AND FLOWERING OF DENDRANTHEMA GRANDIFLORA POT PLANT PRODUCTION
}

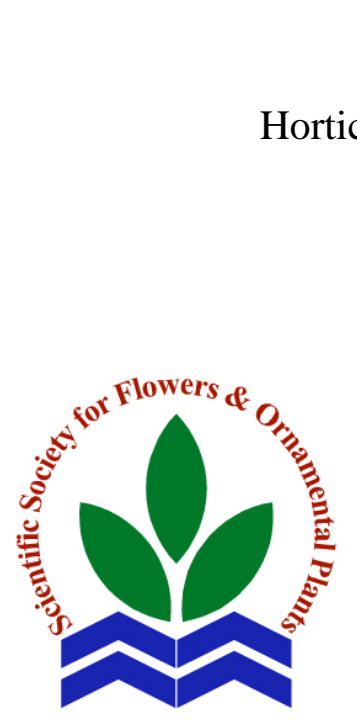

Scientific J. Flowers \& Ornamental Plants, 7(1):1-9 (2020).

Received:

$5 / 1 / 2020$

Accepted:

29/1/2020

\author{
Z.K. Salih and A.N. Hussen
}

Horticulture \& Landscape Dept., Agric. Coll., Tikrit Univ., Iraq

ABSTRACT: The experiment was conducted in Tikrit city, Iraq during the period from May to December 2019 on Dendranthema grandiflora. The objective of this study was to evaluate the use of night break to prolong marketing period of the plant. Two factors were included, the first factor was night break (NB) at five levels (natural day, 5 seconds (flash light), 30, 60 and 120 minutes) starting at 10:00 p.m. for one month. The second one was spraying paclobutrazol at three levels $\left(0,500,1000 \mathrm{mg} \mathrm{l}^{-1}\right)$. The experiment was designed as split plot design, night break was set in the main plot. The results showed that NB had significant effect on values of vegetative growth characteristics. It also delayed the date of initiation and opening of the inflorescences. The treatment of 120 minutes had highest number of days to initiation and opening of flower (167.73 and 183.55 days, respectively), while natural day treatment gave lower number (133.25 and 165.73 days, respectively). The treatment of paclobutrazol at 1000 $\mathrm{mg} \mathrm{l}^{-1}$ concentration gave lowest plant height: pot ratio and highest plant diameter (1.25 and $56.60 \mathrm{~cm}$, respectively). Highest shelf life was 45.10 days at the treatment of interaction between night break of 120 minutes and spraying with paclobutrazol at $1000 \mathrm{mg} \mathrm{l}^{-1}$.

Key words: Dendranthema grandiflora, night break, paclobutrazol, pot plant.

\section{INTRODUCTION}

Dendranthema grandiflora is a perennial herbaceous plant. The genus Dendranthema belongs to the Asteraceae family. It has several names including chrysanthemum (Rose Gold), Autumn Queen and Queen of the East. Chrysanthemum has many uses as ornamental plant. It is produced as loose flowers for making bouquets, and flowering pot plants, and grown in flower beds (Bohra and Kumar, 2014).

Because of the increase in urbanization and the expansion of cities at the expense of lawns and gardens, there has become an increasing demand for flowering and foliage potted plants. These plants are used in several aspects including indoor and decoration inside houses. Colors of their flowers as it express motions inside houses, their perfumes, and purifying air polluted by cooking and manufacture gases, are some features of these plants.

Chrysanthemum is one of the flowering pot plants produced by many companies specialized in ornamental plants. There are many production programs varying according to the plant varieties. Production of dwarfing chrysanthemum in form of a mass of flowers is one of these programs. It is an ancient Japanese method used at the end of the nineteenth century. It was called 


\section{Z.K. Salih and A.N. Hussen}

Fukusuke or Doll as it was believed it brings luck. Plant produced by this method had specific characteristics with height not exceeding 16 inches (Howell, 2007) and (Hall et al., 2006). When producing chrysanthemum as potted plant, there are many factors such as light, temperature, propagation medium, nutrition, and growth regulators need to be considered. The light period, period of exposure to light during the day, affects the growth and flowering of many ornamental including chrysanthemum. This plant is of short daytime that needs 13.5 hours of dark to stimulate flowering. This plant behavior has made it possible to produce it year around. Shortening of summer day or winter night are some of technique used to prolong and control flowering duration and date.

The treatment of night break (NB), which is reducing night time by exposing the plant to light is used by farmers for programming and controlling production period for marketing purposes. In this case, plants can only give vegetative growth with no flowers. Interrupt night time to block the plant from flowering is one technique used in production (Blanchard and Runkle, 2009). Thakur (2016) reported that time of flowering was delayed when NB was increased to $5 \mathrm{sec}$ or $120 \mathrm{~min}$ in $\mathrm{cV}$. Kikiobiory, Snowball and Anmol. In cV. Snowball, NB more than $5 \mathrm{sec}$ inhibited flower bud appearance completely.

Growth retardants are used to produce flowering pot plants with an appropriate size and shape. Growth retardants are non-food organic materials cause plant compaction when used. They inhibit elongation but increase branch number, content of chlorophyll and nutrients. Retardants such as cycocel, alar, and paclobutrazol can inhibit gibberellin production in plant. (Sharifuzzaman et al., 2011). Owners of commercial nurseries experience timing problem of flowering and marketing to a limited tperiod.

Hence, the idea of this research has come to use a NB to prolong duration of flowering and production. Using this technique, more than one batch can be produced during one season. In addition, examining paclobutrazol effect on growth and flowering of chrysanthemum. This can be a beginning to set a production program for chrysanthemum as a flowering pot plant under environment of condition of Salah ElDin Province, Iraq.

\section{MATERIALS AND METHODS}

An experiment was conducted in a nursery at Tikrit city $(180 \mathrm{Km}$ North Baghdad, Iraq). On May $14^{\text {th }} 2019$, three uniform well-rooted transplants of Dendranthema grandiflora cv. Rossinea containing 10-12 leaves were planted in each $18 \mathrm{~cm}$ diameter plastic pot filled with substrate containing mixture of silt, peat moss, and perlite 2:2:1 (v:v:v, respectively) was used. Then, two weeks after transplanting date all plants were pinched at $10 \mathrm{~cm}$ from top of potting medium, remaining 8 leaves for each plant.

This experiment included 15 interaction treatments, which were the combinations between five levels (durations) of night break (NB) and three levels (concentrations) of foliar spray with paclobutrazol.

The five tested NB levels were as follows: L0: plants were subjected to the natural night length for 14 hours, L1: plants were subjected to flash lighting for 5 seconds, L2: plants were subjected to lighting for 30 minutes, L3: plants were subjected to lighting for 60 minutes and L4: plants were subjected to lighting for 120 minutes. The 105-watt LED lamps were used to provide NB treatment rates, and the lamps were mounted $80 \mathrm{~cm}$ above the top of the plant to provide the intended treatments. The plants were treated daily according to the NB treatments planned, starting at 10.00 p.m. for one month (1/9/2019 to 1/10/2019).

The three tested paclobutrazol levels were P0: without paclobutrazol for control, P1: paclobutrazol at $500 \mathrm{mg} \mathrm{l}^{-1}$ and P2: paclobutrazol at $1000 \mathrm{mg} \mathrm{l}^{-1}$. On June, $20^{\text {th }}$ (twenty days after pinching) paclobutrazol 
was applied as foliar spray. A spreading agent Super Film at $1 \mathrm{ml} \mathrm{l}^{-1}$ was used. Plants were sprayed till run off using hand sprayer, and the control treatment was sprayed with tap water containing the spreading agent.

The experimental treatments were set as a split-plot experiment $(5 \times 3)$ between the above-mentioned NB and paclobutrazol levels, with three replicates, each replicate contained three pots. The NB levels were set in main plots, while paclobutrazol concentrations were in sub plots.

Throughout the experimental period, pots were irrigated whenever needed. Also, Peters professional soluble fertilizer (20:20:20) was applied for all treatments at $1.5 \mathrm{~g} \mathrm{l}^{-1}$. It was added twice a week for 6 weeks then as one addition per week at a concentration of $0.5 \mathrm{~g} \mathrm{l}^{-1}$. Additionally, highpotash fertilizer (Peters Professional) 12-043 was added at the beginning of flower bud initiation (early September). It was applied at $1.5 \mathrm{~g} \mathrm{l}^{-1}$ weekly until flower inflorescences opened at the end of October. A $1.5 \mathrm{~g} \mathrm{l}^{-1}$ fungicide (Thanatephorus) was used at the beginning of planting as a preventive spray and repeated monthly. A humic acid was added at $1 \mathrm{~g} \mathrm{l}^{-1}$ once a month during growth stage.

Characters studied were included plant height $(\mathrm{cm})$, plant height $(\mathrm{cm})$ to pot height (cm) ratio (plant height: pot height) and plant diameter $(\mathrm{cm})$. While, flowering responses were recorded as days needed from planting to appearance the first flowering bud on plant (flowering time, days) and days needed from planting to opening the first inflorescence on plant. Additionally, shelf life as days from opening 2-3 inflorescence until color fading was recorded (CarvalhoZanao et al., 2012).

The collected data were subjected to statistical analysis according to SAS Program (1994) and mean separation was done using Duncan's multiple range test at 5\% level (Duncan, 1955).

\section{RESULTS AND DISCUSSION}

There were significant differences between the treatments. The treatment a night break (NB) to 120 minutes had highest value of plant height $(24.27 \mathrm{~cm})$ compared to the lowest value under natural day treatment $(22.94 \mathrm{~cm})$. Treatment with no paclobutrazol spraying was significantly greater than treatment of paclobutrazol spraying. The plant height was $24.93 \mathrm{~cm}$ with no paclobutrazol, while was $22.30 \mathrm{~cm}$ when spraying with $1000 \mathrm{mg} \mathrm{l}^{-1}$ (Fig., 1).

It was found that there were significant differences between treatments in plant diameter. NB treatment for 120 minutes had largest diameter of the plant $54.66 \mathrm{~cm}$. Lowest diameter was under natural day treatment $(52.75 \mathrm{~cm})$. The treatment of

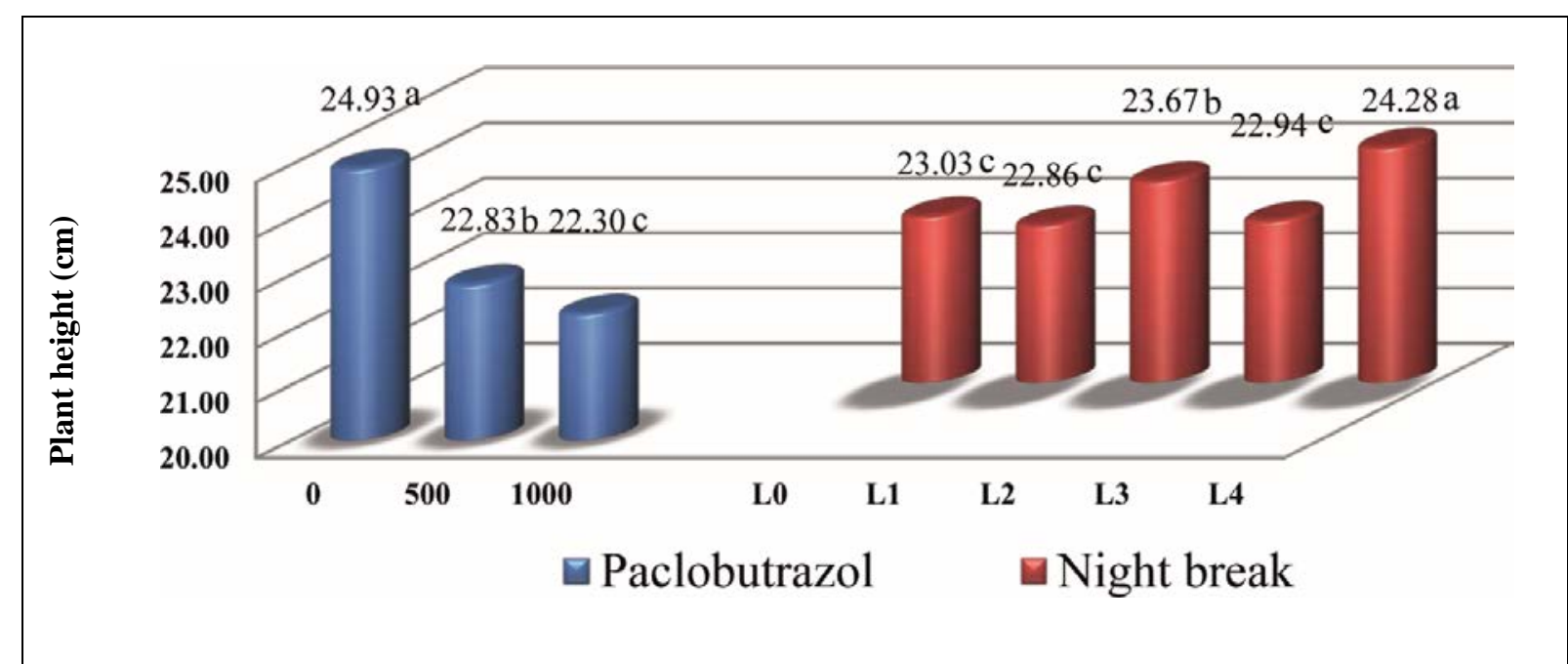

Fig. 1. Effect of night break durations and foliar spray of paclobutrazol on plant height (cm) of Dendranthema grandiflora. 


\section{Z.K. Salih and A.N. Hussen}

paclobutrazol at $1000 \mathrm{mg} \mathrm{l}^{-1}$ resulted in the largest diameter $(55.73 \mathrm{~cm})$ compared to lowest diameter $(51.45 \mathrm{~cm})$ without spraying (Fig., 2).

There were significant differences in ratio of plant height to pot height between treatments. The treatments of 5 seconds and 120 minutes resulted in lowest ratio, 1.27 and 1.29 , respectively. Treatments of natural day, NB for 30 and 60 minutes had highest ratio of plant height to pot height as 1.33 and 1.32, respectively. The plants without paclobutrazol produced the highest ratio (1.39) compared to the lowest ratio (1.25) which was obtained by paclobutrazol at 1000 $\mathrm{mg} \mathrm{l}^{-1}$ (Fig., 3).
Natural day treatment had significant effect on date of flower bud appearance (time to first appearance). Earliest date was 133.254 days under natural day compared to latest date (167.735 days) under 120 minutes of NB. Plants without spraying paclobutrazol had less time to first flower bud appearance (52.261 days) compared to more time needed under treatment with paclobutrazol at 500 and $1000 \mathrm{mg} \mathrm{l}^{-1}$ as recorded 153.595 and 153.639 days, respectively (Fig., 4).

There were significant differences in time of the inflorescences opening. Treatment of natural day exhibited less time to first inflorescences opening (165.73 days) compared to long time needed under

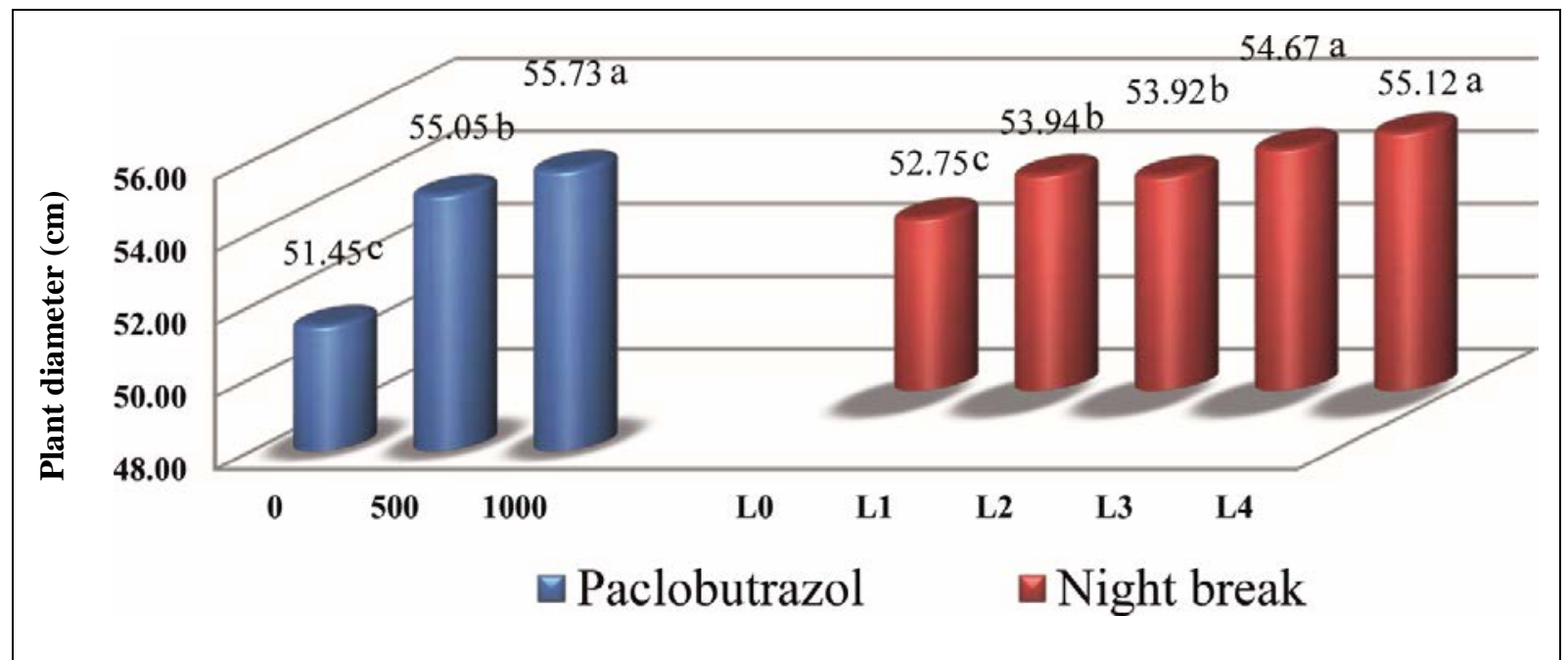

Fig. 2. Effect of night break durations and foliar spray of paclobutrazol on plant diameter (cm) of Dendranthema grandiflora.

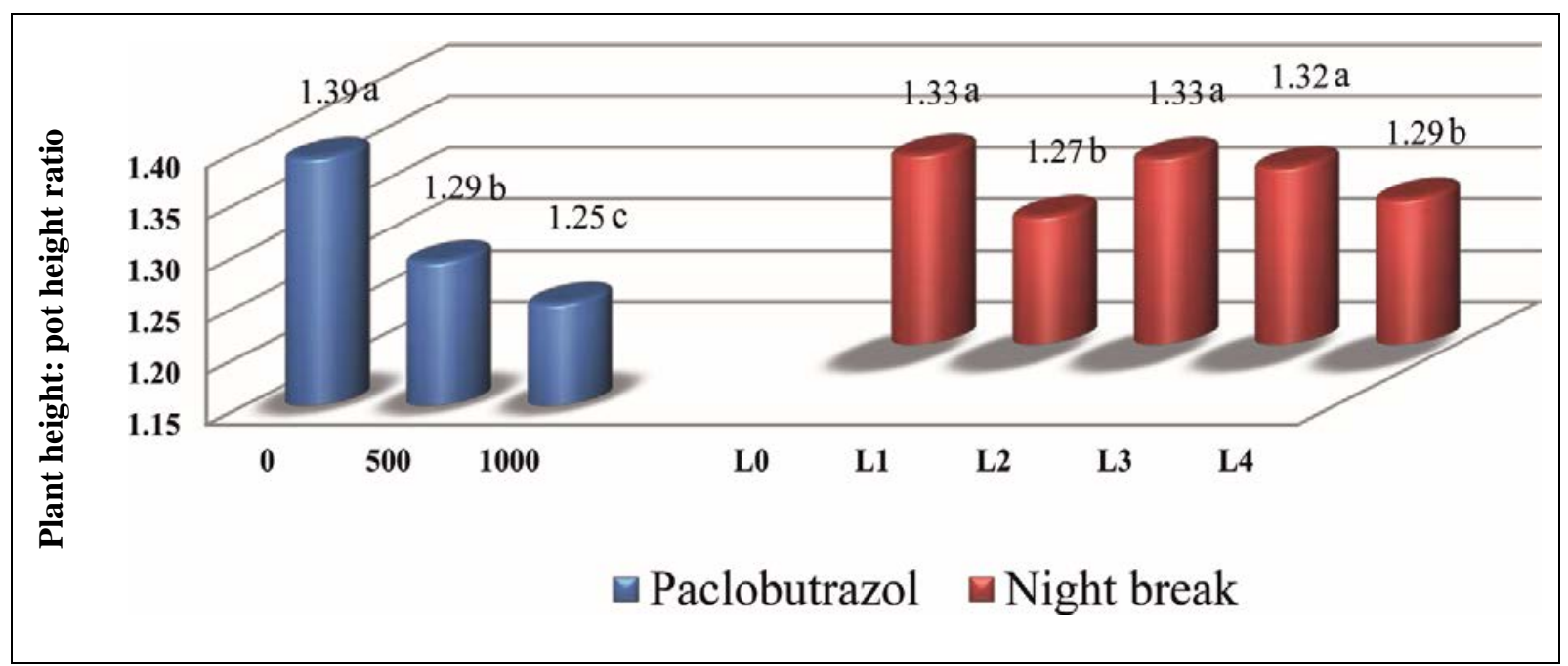

Fig. 3. Effect of night break durations and foliar spray of paclobutrazol on plant height: pot height ratio of Dendranthema grandiflora. 


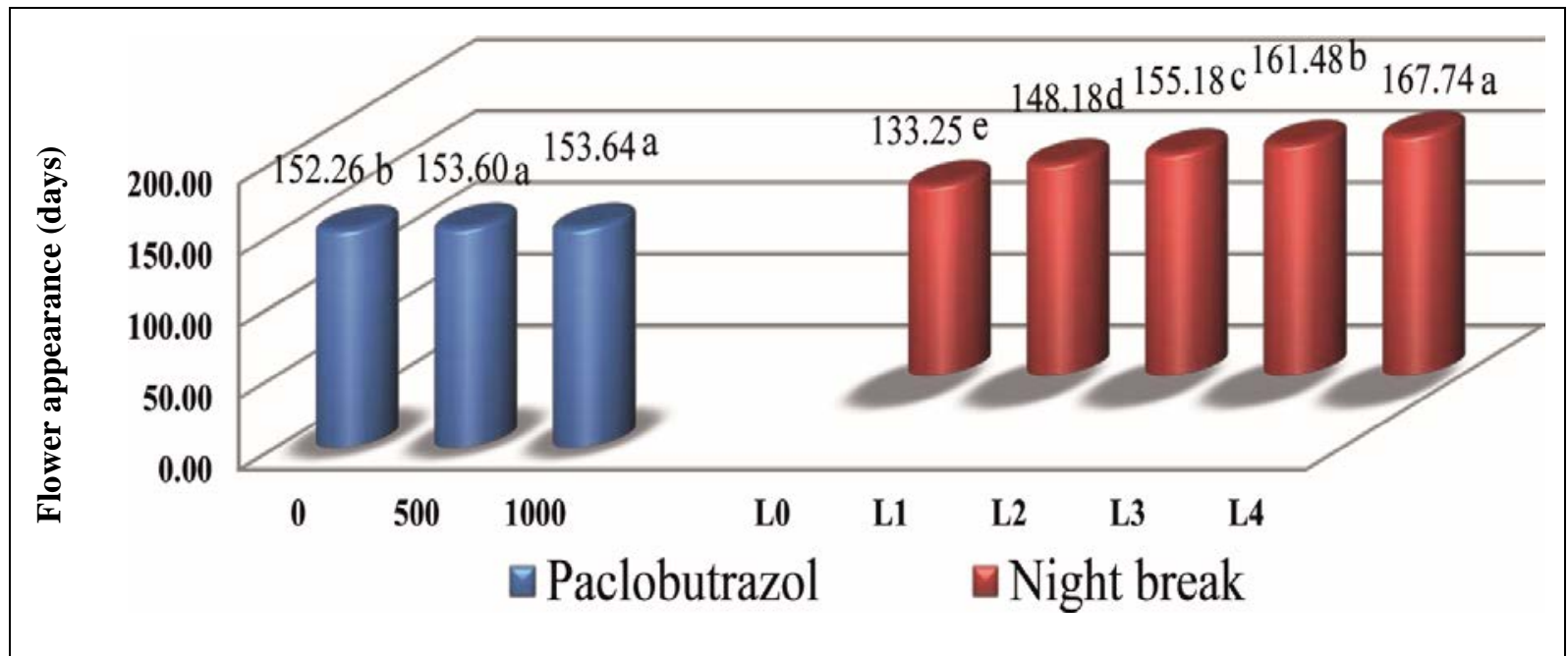

Fig. 4. Effect of night break durations and foliar spray of paclobutrazol on flower appearance (days) of Dendranthema grandiflora.

treatment of NB as 60 and 120 min (183.698 and 183.55 day, respectively). Treatments of paclobutrazol at 500 or $1000 \mathrm{mg} \mathrm{l}^{-1}$ exhibited less time (176.86 and 176.57 days, respectively) compared to long time which obtained without spray (178.61 day) (Fig., $5)$.

The different treatments exhibited different significant effects on shelf life trait. Treatment of NB for $120 \mathrm{~min}$ showed the longest shelf life (42.36 days) compared to the shortest time under treatment of natural day 35.58 days. Treatment of paclobutrazol at $1000 \mathrm{mg} \mathrm{l}^{-1}$ showed the longest shelf life
(41.68 days) compared the shortest shelf life (36.43 days) of plants without spray (Fig., 6).

For the interaction between treatments for NB 120 min and without paclobutrazol produced the highest plant height $(26.25 \mathrm{~cm})$ compared to lowest height $(21.58 \mathrm{~cm})$ when treating NB for $5 \mathrm{sec}+$ paclobutrazol at 1000 $\mathrm{mg} \mathrm{l}^{-1}$. Interaction between NB for $120 \mathrm{~min}$ and spraying paclobutrazol at $1000 \mathrm{mg} \mathrm{l}^{-1}$ showed the highest value of plant diameter $57.08 \mathrm{~cm}$ compared to lowest value 50.00 $\mathrm{cm}$ obtained by natural day without paclobutrazol. On the other hand, treatment

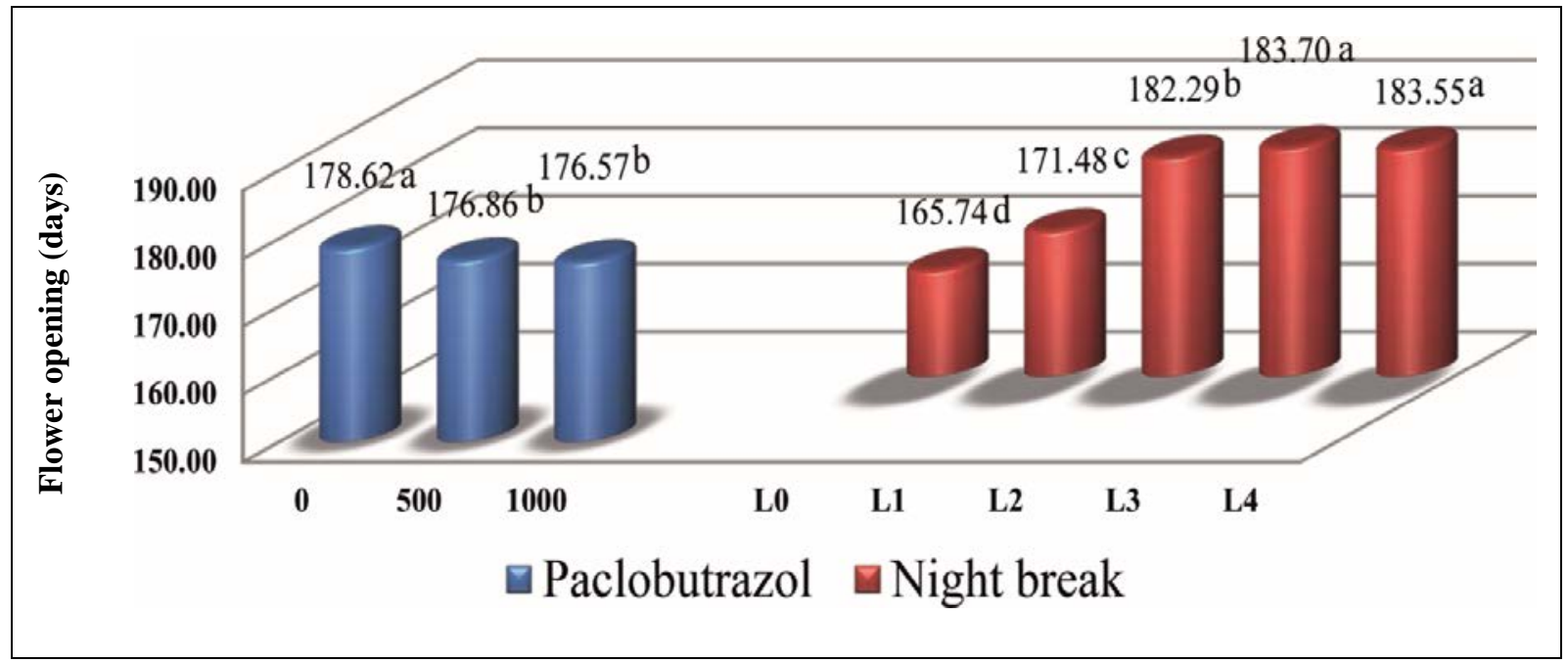

Fig. 5. Effect of night break durations and foliar spray of paclobutrazol on flower opening (days) of Dendranthema grandiflora. 


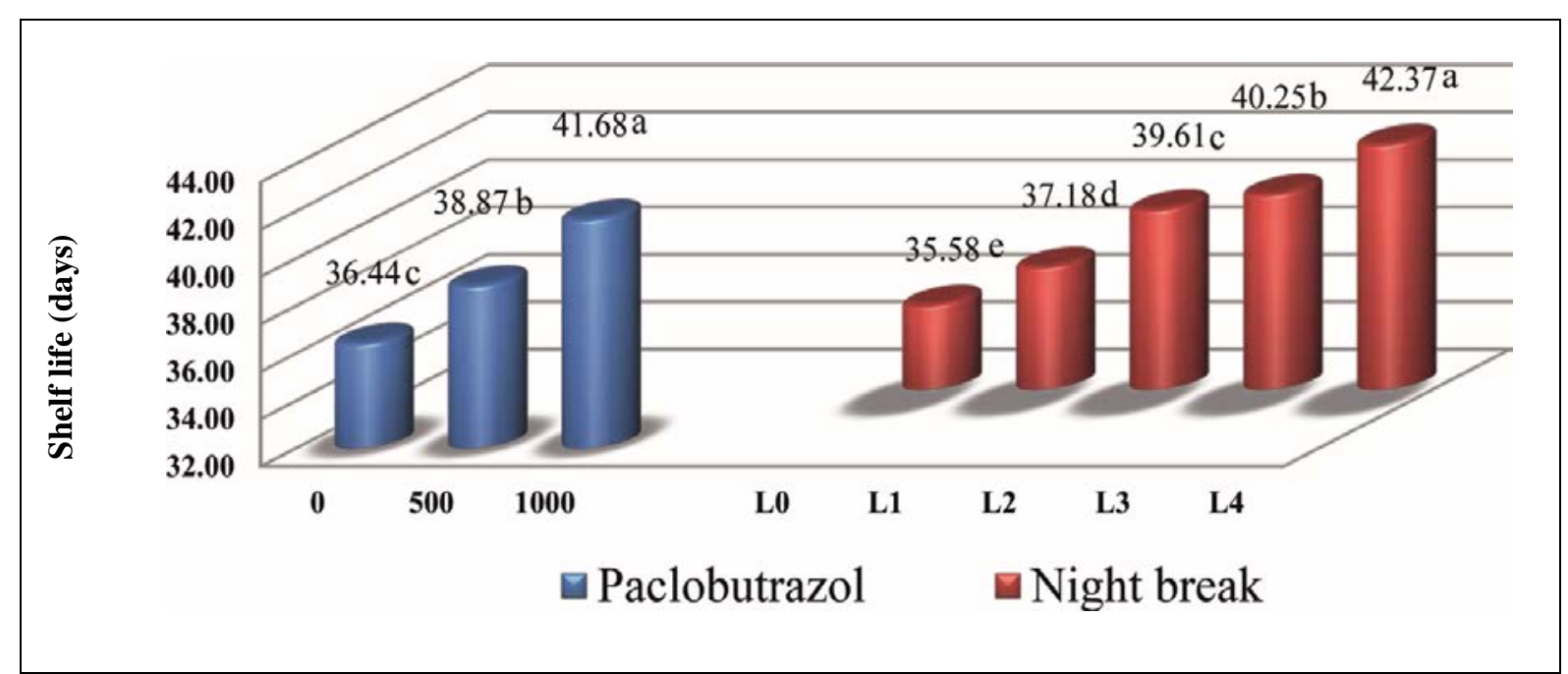

Fig. 6. Effect of night break durations and foliar spray of paclobutrazol on shelf life (days) of Dendranthema grandiflora.

of the interaction between natural day and without paclobutrazol exhibited highest value of plant height: pot height ratio (1.48) compared to less ratio (1.26) under treatment of NB for $120 \mathrm{~min}$ and paclobutrazol at 1000 $\mathrm{mg} \mathrm{l}^{-1}$. Treatment of the interaction between natural day and no paclobutrazol or paclobutrazol at 500 and $1000 \mathrm{mg} \mathrm{l}^{-1}$ showed the less time to first flower bud appearance (132.88, 134.10, and 132.77 days, respectively) compared to NB $120 \mathrm{~min}$ without paclobutrazol (167.55 days). The Interaction between NB and paclobutrazol was significant in plants under natural day with paclobutrazol at $1000 \mathrm{mg} \mathrm{l}^{-1}$. The plants showed less time to first inflorescences opening (164.10 days) compared to longest time (185.44 day) under treatment of NB for 60 min without paclobutrazol. The Interaction between NB for $120 \mathrm{~min}$ and paclobutrazol at $1000 \mathrm{mg} \mathrm{l}^{-1}$ showed the longest shelf life (45.10 days) compared to shortest time (33.47 days) under treatment of interaction between natural day without paclobutrazol (Table, 1).

In the present study, it was observed that flowering under all photoperiodic treatments (Figs., 4 and 5) compared to the control as the plants kept under the natural day length (control) completed their short day requirement earlier for initiation and development of flower buds than different duration of photoperiodic treatments. Light regulated flowering by adjusting the activity of phytochromes. There were two light absorbing forms of phytochromes, biologically active Pfr and inactive Pr, which have maximum absorption spectra at $668 \mathrm{~nm}$ and $730 \mathrm{~nm}$, respectively (Kelly and Lagarias, 1985). Phytochromes can be induced physiologically active Pfr form in continued $\mathrm{R}$ light because of photoreversibility. In the night time, the Pfr form of PhyB had been photoconverted to the inactive Pr form gradually; and since there was no $\mathrm{R}$ light, it was called dark reversion (Medzihradszky et al., 2013). Therefore, the content of PhyA protein declined in the cytoplasm under $\mathrm{R}$ light. In the dark, after the Pfr dropped below the critical level, high transcriptional activity resumed, and PhyA was synthesized in $\mathrm{Pr}$ form that accumulated in the cytoplasm. Therefore, in the short day treatment, PhyA protein decreased during the daytime and increased at night in Arabidopsis (Mockler et al., 2003). Plant height in all night interruption (Fig., 1) increased with the increase in duration of photoperiodic night interruption.

In chrysanthemum for commercial production of pot plant, the plants maintained under long day conditions and optimum night temperature promoted 
Table 1. Effect of the interaction between night break duration and foliar spray of paclobutrazol (PBZ) on growth and flowering of Dendranthema grandiflora.

\begin{tabular}{cccccccc}
\hline $\begin{array}{c}\text { Night } \\
\text { break }\end{array}$ & $\begin{array}{c}\text { PBZ } \\
\left(\mathbf{m g ~ ~ ^ { - 1 }}\right)\end{array}$ & $\begin{array}{c}\text { Plant height } \\
\mathbf{( c m )}\end{array}$ & $\begin{array}{c}\text { Plant } \\
\text { diameter } \\
\mathbf{( c m})\end{array}$ & $\begin{array}{c}\text { Plant } \\
\text { height: } \\
\text { pot height } \\
\text { ratio }\end{array}$ & $\begin{array}{c}\text { Days from planting to } \\
\text { Flower bud } \\
\text { appearance }\end{array}$ & $\begin{array}{c}\text { Inflorescence } \\
\text { opening }\end{array}$ & $\begin{array}{c}\text { Shelf life } \\
\text { (days) }\end{array}$ \\
\hline Natural & $\mathbf{0}$ & $24.24 \mathrm{bc}$ & $50.00 \mathrm{~h}$ & $1.48 \mathrm{a}$ & $132.88 \mathrm{~h}$ & $167.21 \mathrm{~h}$ & $33.47 \mathrm{~h}$ \\
Day & $\mathbf{5 0 0}$ & $22.50 \mathrm{e}-\mathrm{g}$ & $53.66 \mathrm{f}$ & $1.30 \mathrm{ef}$ & $134.10 \mathrm{~h}$ & $165.88 \mathrm{~h}$ & $35.94 \mathrm{f}$ \\
& $\mathbf{1 0 0 0}$ & $22.33 \mathrm{e}-\mathrm{g}$ & $54.58 \mathrm{ef}$ & $1.22 \mathrm{~g}$ & $132.77 \mathrm{~h}$ & $164.10 \mathrm{i}$ & $37.32 \mathrm{e}$ \\
& $\mathbf{0}$ & $24.66 \mathrm{~b}$ & $51.66 \mathrm{~g}$ & $1.37 \mathrm{bc}$ & $145.88 \mathrm{~g}$ & $173.10 \mathrm{e}$ & $34.88 \mathrm{~g}$ \\
$\mathbf{5}$ & $\mathbf{5 0 0}$ & $22.33 \mathrm{e}-\mathrm{g}$ & $54.83 \mathrm{de}$ & $1.27 \mathrm{f}$ & $148.77 \mathrm{f}$ & $169.88 \mathrm{~g}$ & $36.21 \mathrm{f}$ \\
seconds & $\mathbf{1 0 0 0}$ & $21.58 \mathrm{~g}$ & $55.33 \mathrm{c}-\mathrm{e}$ & $1.17 \mathrm{~h}$ & $149.88 \mathrm{f}$ & $171.44 \mathrm{f}$ & $40.44 \mathrm{c}$ \\
& $\mathbf{0}$ & $24.91 \mathrm{~b}$ & $52.25 \mathrm{~g}$ & $1.41 \mathrm{~b}$ & $154.44 \mathrm{e}$ & $183.10 \mathrm{bc}$ & $36.94 \mathrm{ef}$ \\
$\mathbf{3 0}$ & $\mathbf{5 0 0}$ & $23.16 \mathrm{c}-\mathrm{e}$ & $53.66 \mathrm{f}$ & $1.30 \mathrm{ef}$ & $154.88 \mathrm{e}$ & $182.21 \mathrm{~cd}$ & $39.44 \mathrm{~cd}$ \\
minutes & $\mathbf{1 0 0 0}$ & $22.91 \mathrm{~d}-\mathrm{f}$ & $55.83 \mathrm{~b}-\mathrm{d}$ & $1.27 \mathrm{f}$ & $156.21 \mathrm{~d}$ & $181.55 \mathrm{~d}$ & $42.44 \mathrm{~b}$ \\
& $\mathbf{0}$ & $24.58 \mathrm{~b}$ & $51.50 \mathrm{~g}$ & $1.36 \mathrm{~cd}$ & $160.55 \mathrm{c}$ & $185.44 \mathrm{a}$ & $37.77 \mathrm{e}$ \\
$\mathbf{6 0}$ & $\mathbf{5 0 0}$ & $22.41 \mathrm{e}-\mathrm{g}$ & $56.66 \mathrm{ab}$ & $1.29 \mathrm{ef}$ & $161.99 \mathrm{~b}$ & $183.10 \mathrm{bc}$ & $39.88 \mathrm{~cd}$ \\
minutes & $\mathbf{1 0 0 0}$ & $21.83 \mathrm{fg}$ & $55.83 \mathrm{~b}-\mathrm{d}$ & $1.31 \mathrm{ef}$ & $161.88 \mathrm{~b}$ & $182.55 \mathrm{~cd}$ & $43.10 \mathrm{~b}$ \\
& $\mathbf{0}$ & $26.25 \mathrm{a}$ & $51.83 \mathrm{~g}$ & $1.32 \mathrm{de}$ & $167.55 \mathrm{a}$ & $184.21 \mathrm{ab}$ & $39.10 \mathrm{~d}$ \\
$\mathbf{1 2 0}$ & $\mathbf{5 0 0}$ & $23.75 \mathrm{~b}-\mathrm{d}$ & $56.43 \mathrm{a}-\mathrm{c}$ & $1.28 \mathrm{ef}$ & $168.21 \mathrm{a}$ & $183.21 \mathrm{bc}$ & $42.88 \mathrm{~b}$ \\
minutes & $\mathbf{1 0 0 0}$ & $22.83 \mathrm{~d}-\mathrm{f}$ & $57.08 \mathrm{a}$ & $1.26 \mathrm{f}$ & $167.44 \mathrm{a}$ & $183.21 \mathrm{bc}$ & $45.10 \mathrm{a}$ \\
\hline
\end{tabular}

In a vertical column, means having similar letters do not differ significantly according to Duncan's Multiples Range Test at 0.05 level of significance. (PBZ, paclobutrazol).

vegetative growth and stem length before flower induction grown for year round flowering with long stems, the exposure of plants to long day treatment during the critical phase shifted the balance of hormones leading to increase in gibberellins like substances that resulted in significant vegetative growth.

The increase in plant height and growth rate resulted du to enhanced photosynthetic activities under artificial long day conditions accompanied by accumulation of carbohydrate and nitrogen in the treated plants (Datta and Gupta, 2012; Kurilcik et al., 2008). The reduction in internodal length with paclobutrazol application might be due to inhibitory role of growth retardants on cell division and cell elongation of apical meristematic cells and also on the $\mathrm{GA}_{3}$ biosynthesis. Due to the reducing level of $\mathrm{GA}_{3}$, which ultimately leads to the shortening of internodes, is well-known inhibitor of gibberellins biosynthesis as it specifically inhibits the microsomal oxidation of ent- kaurene in the isoprenoid pathway of GAbiosynthesis. The increased plant spread might be due the increase in the number of branches and diameter of plant thereby increased plant spread (Davis et al., 1988).

\section{REFERENCES}

Bohra, M. and Kumar, A. (2014). Studies on effect of organic manure and bioinoculants on vegetative and floral attributes of chrysanthemum cv. Little darling. The Bioscan, 9(3):1007-1010.

Blanchard, M.G. and Runkle, E.S. (2009). Use of a cyclic high-pressure sodium lamp to inhibit flowering of chrysanthemum and velvet sage. Scientia Hort., 122:448-54.

Carvalho-Zanao, M.P.; Junior, L.A.Z.; Barbosa, J.G.; Grossi, J.A.S. and Avila, V.T. (2012). Yield and shelf life of chrysanthemum in response to the silicon application. Horticultura Brasileira, 30:403-408. 
Datta, S.K. and Gupta, V.K. (2012). Year round cultivation of garden chrysanthemum morifolium Ramat) through photoperiodic response. Sci. Culture, 78(1-2):71-77.

Davis, T.D; George, L.S. and Sankhla, N. (1988). Growth retardants as aid in adapting new floriculturist crops to pot culture. Acta Hort., 252:77-84.

Duncan, D.B. (1955). Multiple range and multiple $\mathrm{F}$ test. Journal of Biometrics, 11:1-42.

Hall, C.R.; Hodges, A.W. and Haydu, J.J. (2006). The economic impact of the green industry in the United States. HortTech., 16:345-353.

Howell, R. (2007). Fukusukes-Aren't They Charming. Journal of the National Chrysanthemum Society, https://www.m ums.org/journal.

Kelly, J.M. and Lagarias, J.C. (1985). Photochemistry of 124-kilodalton Avena phytochrome under constant illumination in vitro. Biochemistry, 24:6003-6010.

Kurilcik, A.; Dapkuniene, S.; Kurilcik, G.; Zilinskaite, S.; Zukauskas, A. and Duchovskis, P. (2008). Effect of the photoperiod duration on the growth of chrysanthemum plantlets in vitro. Scientific work of the Lithunian Institute of Horticulture and Lithunian Institute of Agriculture. Sodininkyste Ir Daržininkyste, 27(2):39-46.

Medzihradszky, M; Bindics, J.; Ádám, É.; Viczián, A.; Klement, É. and Nagy, F. (2013). Phosphorylation of phytochrome B inhibits light-induced signaling via accelerated dark reversion in Arabidopsis. Plant Cell, 25:535-544.

Mockler, T.; Yang, H.; Yu, X.; Parikh, D.; Cheng, Y.C.; Dolan, S. and Lin, C. (2003). Regulation of photoperiodic flowering by Arabidopsis photoreceptors. Proc. Natl. Acad. Sci., 100(4):2140-2145.

SAS Program (1994). SAS/ STAT User's Guide: Statistics, Vers. 6.04, $4^{\text {th }}$ Ed., SAS Institute Inc., Cary, N.C., USA.

Sharifuzzaman, S.M.; Ara, K.A.; Rahman, M.H.; Kabir, K. and Talukdar, M.B. (2011). Effect of GA, CCC and MH on vegetative growth, flower yield and quality of chrysanthemum. Int. J. Expt. Agric., 2(1):17-20.

Thakur, T. (2016). Effect of Photoperiod, Nitrogen and Growing Media on Morphological Development of chrysanthemum (Chrysanthemum morifolium Ramat.). Ph.D Thesis of Floriculture and Landscaping, Punjab Agricultural University, Ludhiana, Punjab, India, 93 p.

\section{Dendranthema grandiflorasiاثير معاملة كسر الظلام والباكلوبترازول في انتاج الداوديو كنبات أصيص مزهر التاودي}

$$
\text { قسم البستنه و هندسة الحدائق، كلية والزمد اعلة، جامعة تكريت حسين، العر اق }
$$

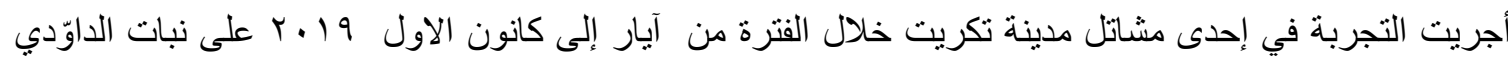
المendranthema grandiflora

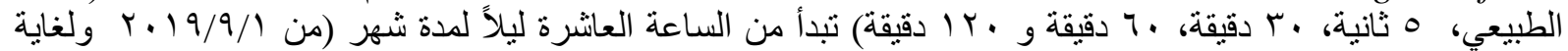

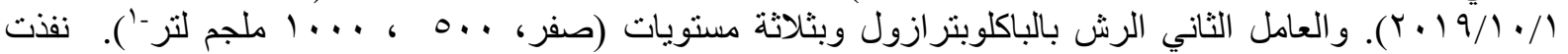

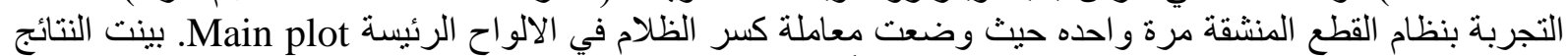

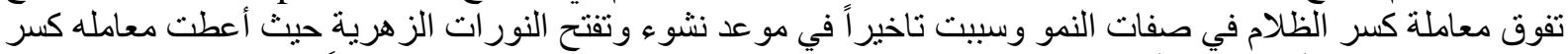

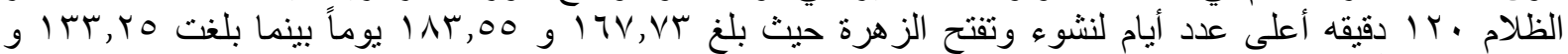

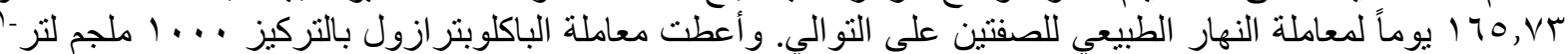


Scientific J. Flowers \& Ornamental Plants, 7(1):1-9 (2020)

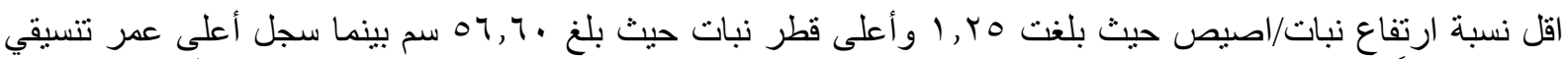

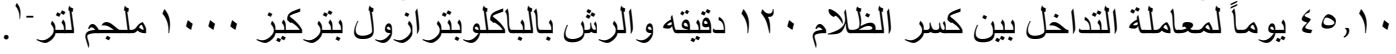

